BIOMEDICAL AND BIOSOCIAL ANTHROPOLOGY
Official Journal of the International Academy
of Integrative Anthropology
journal homepage: http://bba-journal.com

\title{
Quantitative morphological evaluation of structural reconstruction in endothelial cells of arteries and veins of testes in the conditions at postresection pulmonary arterial hypertension
}

\section{Hnatjuk M. S., Konovalenko S. O., Tatarchuk L. V., Jasinovskyy O. B.}

Ternopil National Medical University named by I. Ya. Horbachevsky, Ternopil, Ukraine

\section{ARTICLE INFO}

Received: 20 September, 2019

Accepted: 23 October, 2019

UDC: $616.131-008,331.1-06.616 .127-$ 008

\section{CORRESPONDING AUTHOR}

e-mail: hnatjuk@tdmu.edu.ua Hnatjuk M. S.
Removal of the right or left lung can lead to postresection pulmonary arterial hypertension, venous stasis in the organs of the great circle of blood circulation and structural and functional changes in them. Morphological reconstruction of endotheliocytes of arteries and veins of testes at postresection pulmonary arterial hypertension are insufficiently studied. The purpose of our study was to conduct a quantitative morphological evaluation of structural changes of endothelial cells of the arteries and veins of the testes at postresection pulmonary arterial hypertension. The testes of 46 white male rats, which were divided into 3 groups, were morphological examined. The 1 st group consisted of 14 intact animals, 2st - 22 rats with postresection pulmonary arterial hypertension and compensated cor pulmonale, 3st - 10 animals with postresection pulmonary hypertension and decompensated cor pulmonale. Postresection pulmonary arterial hypertension and cor pulmonale were modeled by performing right pulmonectomy in rats. Euthanasia of rats was performed by bloodletting under conditions of thiopental anesthesia one month after the start of the experiment. From the testes were made micropreparations, which morphometrically determined the height of endothelial cells of arteries and veins, the diameter of their nuclei, nuclear-cytoplasmic ratios in these cells, the relative volumes of damaged endotheliocytes. Quantitative indicators were processed statistically. In the conditions of postresection pulmonary arterial hypertension and decompensated pulmonary heart, the studied morphometric parameters changed most markedly. The height of endothelial cells of the arteries of the left testis was reduced by $2.9 \%(p<0.05)$, and the right - by $2.3 \%$. Nuclear-cytoplasmic ratios in the endotheliocytes of these vessels increased by $7.6 \%$ and $4.7 \%$, respectively $(p<0.05)$, and the relative volume of damaged endotheliocytes increased by 11.7 and 9.3 times $(p<0.001)$. The studied morphometric parameters in the testicular veins increased to a greater extent compared with the arteries. Thus, the height of endothelial cells of the left testis in the 3rd group of observations was statistically significant $(p<0.001)$ decreased by $5.8 \%$, and in the right - by $5.4 \%$. Nuclear-cytoplasmic ratios in the studied structures increased by $8.2 \%(p<0.001)$ and $6.5 \%(p<0.01)$, respectively, which indicated a pronounced violation of structural cellular homeostasis. The relative volume of damaged endothelial cells in the veins of the left testis in postresection pulmonary arterial hypertension combined with decompensated heart increased by 17.6, in the right - by 13.0 times $(p<0.001)$. Optical on histological preparations of testes showed plethora and dilation of venous vessels, which was complicated by hypoxia, dystrophy, necrobiosis of cells and tissues of the studied organ, and in the long term - infiltrative and sclerotic processes. Venous vessels of the microhemocirculatory bed are unevenly dilated, tortuous, full-blooded, with numerous varicose veins and sacculations. Stasis, thrombosis, diapedetic hemorrhages, plasmorrhagia of the walls of venous vessels and paravasal tissues were found in these vessels. Elastic structures in vessels with the phenomena of multiplication, fragmentation and destruction. Endotheliocytes with signs of edema, dystrophically and necrobiotically altered, sometimes desquamated. Analysis of the obtained data revealed that postresection pulmonary arterial hypertension leads to violations of cellular structural homeostasis, an increase in the relative volumes 
of damaged endotheliocytes in the vascular bed of the testes. The revealed processes dominate in the venous bed of the left testis and in the decompensated cor pulmonale. Keywords: postresection pulmonary hypertension, testes, endotheliocytes, arteries, veins, morphometry.

\section{Introduction}

Lung resections are often performed today in modern surgical clinics for benign and malignant tumors, metastases, injuries, tuberculosis, alveolar echinococcosis, lung transplantation [10, 13, 15]. Removal of the lung can lead to various post-resection complications: hypertension in the small circle of blood circulation, pulmonary heart, cardiovascular failure, arrhythmias, postpneumonectomy edema of the single lung, thromboembolism of the branches of the pulmonary artery, postpneumonectomy syndrome bronchopleural fistulas, pleural empyema and others [15, 16, 19]. Postresection pulmonary arterial hypertension leads to structural reorganization of the circulatory system, as well as remodeling of their structures. The testis belongs to the organs whose hemodynamic disorders are complicated by various morphological changes in the vascular bed and their structures. It should be noted that the features of remodeling of testicular structures in postresection pulmonary arterial hypertension have not been studied enough $[3,9,14,16]$.

In recent years, morphologists are increasingly using morphometric research methods that allow to quantify and most objectively assess various physiological and pathological processes in organs and systems and logically interpret them $[3,4,17]$.

The aim of the study was to conduct a quantitative morphological assessment of structural changes in endothelial cells of testicular arteries and veins in the conditions of postresection pulmonary arterial hypertension.

\section{Materials and methods}

The testes of 46 laboratory adult white male rats, which were divided into 3 groups, were studied by a complex of morphological methods. The 1st group consisted of 14 intact animals, the 2 nd - 22 rats with postresection pulmonary arterial hypertension and compensated pulmonary heart, the 3rd - 10 animals with postresection pulmonary arterial hypertension and decompensated pulmonary heart.

All manipulations and euthanasia of rats were carried out in accordance with the basic principles of work with experimental animals in the provisions of the "European Convention for the protection of vertebrate animals used for experimental and other purposes" (Strasbourg, 1986), "General ethical principles of animal experiments" adopted by the first national Congress on Bioethics (Kyiv, 2001), as well as the Law of Ukraine "About protection of animals from cruel treatment" (from 21.02.2006) [1], the order of the Ministry of Education and Science, Youth and Sports of Ukraine № 249 from 01.03.2012. animals "Procedures for scientific institutions to conduct experiments on animals".

Postresection pulmonary arterial hypertension and pulmonary heart were modeled by performing right-sided pulmonectomy in rats $[5,16,17]$. In 10 animals after this operation developed decompensated pulmonary heart. The latter was confirmed in rats by shortness of breath, cyanosis of the mucous membranes, hydrothorax, hydropericardium, congestion in the circulatory system, peripheral edema. Euthanasia of rats was performed by bloodletting under conditions of thiopental-sodium anesthesia (40 mg/kg intraperitoneally) one month after the start of the experiment. Separate weighing and planimetry of the heart chambers were performed. Pieces were cut from the testes, which were fixed in a $10 \%$ solution of formalin, passed through ethyl alcohols of increasing concentration and placed in paraffin. Microtome sections after dewaxing were stained with hematoxylin-eosin, according to the method of Weigert, Van Gieson's, Mallory, toluidine blue $[1,6]$.

Morphometrically in the left (LT) and right (RT) testicles measured the height of endothelial cells of arteries (HEA) and veins (HEV), the diameter of endothelial cells of arteries (DEA) and veins (DEV), nuclear-cytoplasmic ratios in these cells (NCRA, NCRV), as well as the relative volumes of damaged endothelial cells of arteries (RVDEA) and veins (RVDEV) $[4,5]$.

Quantitative morphological parameters were processed statistically. Processing of the latter was performed in the Department of System Statistical Surveys of Ternopil National Medical University named by I. Ya. Horbachevsky of the Ministry of Health of Ukraine using the software "STATISTICA" ("Statsoft", USA). The difference between the comparative morphometric parameters was determined by the criteria of Student and Mann-Whitney [7, 11].

\section{Results}

Separate weighing and planimetry of the heart revealed that a month after right-sided pulmonectomy in all observations revealed hypertrophy and dilatation of the heart chambers with a predominance of weight gain and expansion of the right ventricle, ie the development of the pulmonary heart.

The obtained morphometric parameters of vascular endothelial cells of the left and right testes of experimental animals are presented in Table 1.

A comprehensive analysis of the data in the table shows that most of them have changed markedly. Thus, in postresection arterial pulmonary hypertension and compensated pulmonary heart, the studied morphometric parameters of the arteries of the left testis changed slightly. 
Table 1. Morphometric characteristics of endotheliocytes of arteries and veins of testes of experimental animals $(M \pm m)$.

\begin{tabular}{|c|c|c|c|}
\hline \multirow{2}{*}{ Indicators } & \multicolumn{3}{|c|}{ Observation group } \\
\hline & $1 \mathrm{st}$ & $2 n d$ & $3 r d$ \\
\hline HEA LT, $\mu \mathrm{m}$ & $6.101 \pm 0.090$ & $6.080 \pm 0.081$ & $5.930 \pm 0.051^{*}$ \\
\hline $\mathrm{DEA} L \mathrm{LT}, \mu \mathrm{m}$ & $3.122 \pm 0.030$ & $3.090 \pm 0.030$ & $3.160 \pm 0.030$ \\
\hline NCRA LT & $0.262 \pm 0.003$ & $0.258 \pm 0.003$ & $0.282 \pm 0.003^{* *}$ \\
\hline RVDEA LT, \% & $2.101 \pm 0.021$ & $4.301 \pm 0.051^{\text {***}}$ & $24.50 \pm 0.27^{\star \star \star}$ \\
\hline HEV LT, $\mu \mathrm{m}$ & $4.802 \pm 0.030$ & $4.550 \pm 0.042^{\star \star}$ & $4.501 \pm 0.030^{* *}$ \\
\hline $\mathrm{DEV} L \mathrm{LT}, \mu \mathrm{m}$ & $3.560 \pm 0.021$ & $3.501 \pm 0.030$ & $3.460 \pm 0.021^{* *}$ \\
\hline NCRV LT & $0.550 \pm 0.003$ & $0.582 \pm 0.003^{* * *}$ & $0.595 \pm 0.004^{\star * *}$ \\
\hline RVDEV LT, \% & $2.202 \pm 0.030$ & $6.580 \pm 0.042^{\star \star \star}$ & $38.70 \pm 0.51^{\star \star \star}$ \\
\hline HEA RT, $\mu \mathrm{m}$ & $6.101 \pm 0.120$ & $6.081 \pm 0.090$ & $5.960 \pm 0.030^{*}$ \\
\hline $\mathrm{DEA} R \mathrm{RT}, \mu \mathrm{m}$ & $3.090 \pm 0.042$ & $3.102 \pm 0.030$ & $3.141 \pm 0.030$ \\
\hline NCRA RT & $0.256 \pm 0.003$ & $0.260 \pm 0.003$ & $0.268 \pm 0.002^{*}$ \\
\hline RVDEA RT, \% & $2.081 \pm 0.042$ & $3.901 \pm 0.030^{* * *}$ & $19.40 \pm 0.18^{\text {** }}$ \\
\hline HEV RT, $\mu \mathrm{m}$ & $4.802 \pm 0.030$ & $4.552 \pm 0.030^{* *}$ & $4.541 \pm 0.030^{\star \star \star}$ \\
\hline DEV RT, $\mu \mathrm{m}$ & $3.560 \pm 0.021$ & $3.500 \pm 0.030$ & $3.470 \pm 0.021^{*}$ \\
\hline NCRV RT & $0.550 \pm 0.003$ & $0.580 \pm 0.003^{\star \star}$ & $0.586 \pm 0.004^{* *}$ \\
\hline RVDEV RT, \% & $2.201 \pm 0.030$ & $6.340 \pm 0.042^{\star \star \star}$ & $28.60 \pm 0.51^{* \star *}$ \\
\hline
\end{tabular}

Under these experimental conditions, the relative volume of damaged endothelial cells of the left testicular arteries increased 2.05 times, in the right -1.88 times $(p<0.001)$, and in the veins - 2.99 times and 2.88 times, respectively $(p<0.001)$.

The studied morphometric parameters of the veins of the left and right testicles in postresection pulmonary arterial hypertension were more pronounced compared with the arteries, which confirmed the nuclear-cytoplasmic ratio in the endotheliocytes of the veins, which increased by $5.8 \%$ in the left testicle $(p<0.001)$ - and in right by $5.4 \%$ $(p<0.01)$. In the conditions of postresection pulmonary arterial hypertension and decompensated pulmonary heart, the studied morphometric parameters changed more significantly compared with the data of the 2 nd group of observations. The height of endothelial cells of the arteries of the left testis was reduced by $2.8 \%(p<0.05)$, and the right - by $2.3 \%$. The nuclear-cytoplasmic ratios in the endotheliocytes of these vessels increased by $7.6 \%$ and $4.7 \%$, respectively $(p<0.05)$, and the relative volume of damaged endotheliocytes increased by 11.7 and 9.3 times $(p<0.001)$.

The studied morphometric parameters in the testicular veins varied to a greater extent compared with the arteries. Thus, the height of endothelial cells of the left testis in the 3rd group of observations was statistically significant $(p<0.001)$ decreased by $6.25 \%$, and in the right - by $5.6 \%$. Nuclear-cytoplasmic ratios in the studied structures increased by $8.2 \%(p<0.001)$ and $6.5 \%(p<0.01)$, respectively, which indicated a pronounced violation of structural cellular homeostasis [4, 5]. The relative volume of damaged endotheliocytes in the veins of the left testis in postresection pulmonary arterial hypertension combined with decompensated heart increased by $17.6(p<0.001)$, in the right - by 13.0 times $(p<0.001)$.

Histologically was observed plethora and dilation of venous vessels, which was complicated by hypoxia, dystrophy, necrobiosis of cells and tissues of the studied organ, and in the long term - infiltrative and sclerotic processes. Venous vessels of the microhemocirculatory tract are unevenly dilated, tortuous, full-blooded, with numerous varicose veins and sacculations. Stasis, thrombosis, diapedetic hemorrhages, plasmorrhagia of the walls of venous vessels and paravasal tissues were found in these vessels. Elastic structures in vessels with the phenomena of multiplication, fragmentation and destruction. Endothelial cells with signs of edema, dystrophically and necrobiotically altered, sometimes desquamated. The revealed structural changes dominated in the left testis and in the conditions of postresection pulmonary arterial hypertension with decompensated heart. The predominance of morphological and morphometric changes in the vessels of the left testis can be explained by the peculiarities of venous outflow from this organ $[2,8]$.

\section{Discussion}

The conducted researches and the received results testify that changes of hemodynamics which take place at a postresection pulmonary arterial hypertension lead to structural reorganization of endothelial cells of arterial and venous channels of testicles. Changes in venous vessels, ie in the drainage systems of the testes [2, 8], were more pronounced compared with arteries. The combination of postresection pulmonary arterial hypertension with decompensated pulmonary heart led to more intense morphological changes in the studied testicular structures, which was confirmed by a significant violation of nuclearcytoplasmic relations in endothelial cells of arteries and veins, as well as a significant increase in relative volume of damaged endotheliocytes [4].

In morphological and morphometric studies of arterial and venous vessels of the testes in postresection pulmonary arterial hypertension, damage to endothelial cells in the above structures was observed. It is believed that the endothelium, which covers the inner surface of blood vessels, is an important auto-, para- and endocrine organ with numerous regulatory functions $[18,20]$. It is known that normally functioning endothelial cells produce nitric oxide (NO), which regulates vascular tone, affects vascular wall remodeling processes, determines the system of antioxidant defense and peroxide aggression, inhibits platelet aggregation and adhesion, macrophages, and proliferative processes in the wall of the vessel [14, 18]. Damage to a significant number of endothelial cells in the studied vessels can lead to endothelial dysfunction, 
which plays a leading role in vascular remodeling and morphogenesis of the studied pathology.

Impaired blood supply, hypoxia lead to a cascade of pathological reactions and the release of pro-inflammatory cytokines, inflammatory mediators, highly active free radicals that adversely affect the intercellular structures surrounding cell membranes, as well as the vascular wall $[3,4,18]$. This damages the basement vascular membrane, interendothelial contacts and endotheliocytes. Under these conditions, the concentration of endothelin-1 in the blood increases, which enhances vasoconstriction of arteries by activating $\mathrm{Ca}^{2+}$-channels, proliferation of endothelial cells, smooth myocytes and vascular wall fibroblasts, apoptosis, causes the expression of adhesive molecules. When endotheliocytes are damaged, intercellular connections are disrupted, which leads to increased permeability of endotheliocytes and violation of their barrier function. Vascular permeability and endothelial barrier dysfunction are complicated by tissue edema and contribute to increased extravasation of inflammatory elements into the paravasal tissues and contribute to the chronicity of the pathological process. This reduces the relaxation function of the endothelium, which is associated with hyperproduction of endothelin-1, decreased synthesis of prostacyclin and deficiency of endogenous NO [12, 20].

\section{References}

[1] Bagrij, M. M., Dibrova, V.A., \& Popadynets, O. G. (2016). Methods of morphological research: monograph. Vinnytsia: A new book.

[2] Bajbakov, V. M. (2011). Morphofunctional changes of the venous bed as a part of the drainage system of the testis in trauma to the vascular anastomoses of the spermatic cord in the experiment. Clinical anatomy and operative surgery, 10(4), 32-35.

[3] Bazalycz ka, S. V. (2016). Male infertility in Ukraine: features of patho- and morphogenesis. Kyiv: Ltd. "Chetvertahvylya".

[4] Hnatjuk, M. S., Tatarchuk, L. V., \& Slabyy, O. B. (2016). Nuclearcytoplasmic relations in cardiomyocytes and ventricular endotheliocytes of the pulmonary heart. Clinical anatomy and operative surgery, (1), 67-70. doi: 10.24061/17270847.15.1.2016.16

[5] Hnatjuk, M. S., Slabyy, O. B., \& Tatarchuk, L. V. (2016). Histostereometric study of structural changes in cor pulmonale in rats. Cardiology in Belarus, 8(1), 73-78.

[6] Goralskyi, L. P., Xomych, V. T., \& Kononskyi, O. I. (2011). Fundamentals of histological technique and morphofunctional research methods in normal and pathology. Zhytomyr: Polissya.

[7] Grzhybovskyi, A. Y., Ivanov, O. V., \& Gorbatova M. A. (2016). Comparison of Quantitative Data of Two Paired Samples Using Statistica and SPSS Software: Parametric and Nonparametric Tests. Science and healthcare, (3), 5-25.

[8] Gryczulyak, B. V., \& Glodan, O. Ya. (2011). Cytological changes in the testis under conditions of blockage of blood flow from it in the experiment. Journal of Vasyl Stefanyk Precarpathian National University. Biology series, (XV), 201-204.

[9] Gryczulyak, B. V., Gryczulyak, V. B., Glodan, O. Ya., Dolynko, O. P., Ivasiuk, I. Y., \& Spaska, A. M. (2019). Histo- and ultrastructural changes in the seminiferous tubules of the testis
Hypoxia is one of the leading components of the damaging effect on the cell. In conditions of oxygen deficiency, the transport of fatty acids across cell membranes increases, the content of free carnitine and the activation of carnitine-dependent oxidation of fatty acids increases. As a result of the described phenomena, the activation of free radical oxidation is enhanced, which leads to damage primarily to mitochondrial membranes, their destruction and degeneration, which significantly reduces the energy supply of cells. It is known that tissue hypoxia contributes to the deprivation of compensatory mechanisms of adaptation and reduces the resistance of cellular structures to the damaging effects of negative metabolic factors $[18,20]$.

\section{Conclusions}

The data obtained indicate that right-sided pulmonectomy leads to postresection pulmonary arterial hypertension, pulmonary heart and is complicated by violations of cellular structural homeostasis, an increase in the relative volumes of damaged endothelial cells in the vascular bed of the testes. The detected processes dominate in the venous bed of the left testis and in the decompensation of the pulmonary heart.

of men of reproductive age in dropsy. Bulletin of problems of biology and medicine, 1(1), 262-264. doi: 10.29254/20774214-2019-1-1148-262-264

[10] Jiang, W. Y., Liao, Y. D., Cai, Y. X., \& Fu, X. N. (2014). Application of pedicled aortic adventitia flapin there in for cement of bronchialstump or bronchial anastomotic stomaclosure in left pulmonary resection. The Journal of Thoracic and Cardiovascular Surgery, 148(1), 351-353. doi: 10.1016/ j.jtcvs.2014.02.007

[11] Lapach, S. N., Gubenko, A. V., \& Babych, P. N. (2001). Statistical Methods in Life Sciences Excell. Kyiv: Morion.

[12] Lucyk, O. D. (2018). Histology. Cytology. Embryology. Vinnytsia: New Book.

[13] Mohajeri, G., Omid, M., Melali, H., Heidarpour, M., \& Jazi, AH. D. (2014). Bronchial stump closure with amniotic membrane in animal model. Journal of Research in Medical Sciences: The Official Journal of Isfahan University of Medical Sciences, 19(3), 211. -214. PMID: 24949027

[14] Markovs`kyi, V. D., \& Tumans`kyi, V. O. (2015). Pathomorphology: a national textbook. K.: VSV " Medicine".

[15] Simonneau, G., Galie, N., Rubin, L. J., Langleben, D., Seeger, W., Domenighetti, G., ... \& Rich, S. (2004). Clinical classification of pulmonary hypertension. Journal of the American College of Cardiology, 43(12 Supplement), S5-S12. doi: 10.1016/ j.jacc.2004.02.037

[16] Slabyi, O. B. (2017). Morphogenesis of postresection of cor pulmonale. Hospital surgery. The magazine named after $L$. Y. Kovalchuk, (3), 109-113. doi: 10.11603/2414-4533.2017.3.8130

[17] Tatarchuk, L. V. (2011). Morphometric analysis of heart chamber remodeling after pulmonectomy. Achievements of clinical and experimental medicine, 2(15), 123-126.

[18] Vozna, X. I. , Moskaliuk V. D., \& Sorokhan, V. D. (2015). Endothelium: functional properties and its dysfunction. Clinical 
and experimental pathology, 14(1), 209-214. doi: 10.11603/ 1681-2727.2015.1.3856

[19] Yablonsky i, P. K. (2014). National clinical guidelines. Thoracic surgery. M.: GEOTAR-Media.
[20] Zharynova, V. Yu. (2015). Endothelial dysfunction as a multidisciplinary problem. Blood circulation and homeostasis, $(1-2), 9-14$

\section{КІЛЬКІСНА МОРФОЛОГІЧНА ОЦІНКА СТРУКТУРНОЇ ПЕРЕБУДОВИ ЕНДОТЕЛІОЦИТІВ АРТЕРІЙ ТА ВЕН СІМ'ЯНИКІВ ПРИ ПОСТРЕЗЕКЦІЙНІЙ ЛЕГЕНЕВІЙ АРТЕРІАЛЬНІЙ ГІПЕРТЕНЗІЇ \\ Гнатюк М. С., Коноваленко С. О., Татарчук Л. В., Ясіновський О. Б.}

Видалення правої або лівої легені може призводити до пострезекційної легеневої артеріальної гіпертензії, венозного застою в органах великого кола кровообігу та структурно-фрункціональних змін у них. Морфологічні зміни в ендотеліоцитах артерій та вен сім'яників при пострезекційній легеневій артеріальній гіпертензії вивчені недостатньо. Метою нашого дослідження стало проведення кількісної морфологічної оцінки структурних змін у ендотеліоцитах артерій та вен сім'яників в умовах пострезекційної легеневої артеріальної гіпертензії. Морфологічно досліджено сім'яники 46 білих щурів-самців, які були розділені на 3 групи. 1-а група нараховувала 14 інтактних тварин, 2-а - 22 щурів з пострезекційною легеневою артеріальною гіпертензією і компенсованим легеневим серцем, 3-я - 10 тварин з пострезекційною легеневою гіпертензією і декомпенсованим легеневим серцем. Пострезекційну легеневу артеріальну гіпертензію і легеневе серце моделювали шляхом виконання у щурів правосторонньої пульмонектомії. Евтаназію щурів здійснювали кровопусканням в умовах тіопенталового наркозу через місяць від початку досліду. З сім'яників виготовляли мікропрепарати, на яких морфоометрично визначали висоту ендотеліоцитів артерій та вен, діаметр їх ядер, ядерно-цитоплазматичні відношення у цих клітинах, відносні об'єми пошкоджених ендотеліоцитів. Кількісні показники обробляли статистично. В умовах пострезекційної легеневої артеріальної гіпертензії та декомпенсованого легеневого серця досліджувані морфометричні параметри змінювалися найбільш виражено. Висота ендотеліоцитів артерій лівого сім'яника виявилася зменшеною на 2,8 \% (p<0,05), а правого - на 2,3 \% порівняно 3 контролем. Ядерно-цитоплазматичні відношення у ендотеліоцитів вказаних судин відповідно збільшувалися на 7,6 \% та 4,7 \% (p<0,05), а відносний об'єм пошкоджених ендотеліоцитів зріс у 11,7 та 9,3 рази (p<0,001). Досліджувані морфрометричні параметри у венах сім'яників змінювалися у більшому ступені порівняно з артеріями. Так, висота ендотеліоцитів вен лівого сім'яника у 3-й групі спостережень статистично значуще $(p<0,001)$ зменшилася на 6,2 \%, а у правому - на 6,0 \%. ядерно-цитоплазматичні відношення у досліджуваних структурах відповідно збільшилися на 8,2 \% $(p<0,001)$ та 7,3 \% $(p<0,01)$, що свідчило про виражене порушення структурного клітинного гомеостазу. Відносний об'єм пошкоджених ендотеліоцитів у венах лівого сім'яника при пострезекційній легеневій артеріальній гіпертензії поєднаної з декомпенсованим серцем збільшився у 17,6, у правому - у 13,0 разів (p<0,001). Світлооптично на гістологічних препаратах сім'яників спостерігалося повнокров'я та розширення венозних судин, що ускладнювалося гіпоксією, дистрофрією, некробіозом клітин та тканин досліджуваного органа, а у віддаленому періоді - інфрільтративними та склеротичними процесами. Венозні судини мікрогемоциркуляторного русла нерівномірно розширені, звивисті, повнокровні, з чисельними варикозними розширеннями та саккуляціями. У вказаних судинах виявлялися стази, тромбози, діапедезні крововиливи, плазморагії стінки венозних судин та паравазальних тканин. Еластичні структури у судинах з явищами мультиплікації, фррагментації та руйнування. Ендотеліоцити з ознаками набряку, дистрофрічно та некробіотично змінені, місцями десквамовані. За допомогою аналізу отриманих результатів встановлено, що пострезекційна легенева артеріальна гіпертензія призводить до порушень клітинного структурного гомеостазу, зростання відносних об'ємів пошкоджених ендотеліоцитів у судинному руслі сім'яників. Виявлені процеси домінують у венозному руслі лівого сім'яника та при декомпенсованому легеневому серці.

Ключові слова: пострезекційна легенева гіпертензія, сім'яники, ендотеліоцити, артерії, вени, морфометрія.

\section{КОЛИЧЕСТВЕННАЯ МОРФОЛОГИЧЕСКАЯ ОЦЕНКА СТРУКТУРНОЙ ПЕРЕСТРОЙКИ ЭНДОТЕЛИОЦИТОВ АРТЕРИЙ И ВЕН} СЕМЕННИКОВ ПРИ ПОСТРЕЗЕКЦИОННОЙ ЛЁГОЧНОЙ АРТЕРИАЛЬНОЙ ГИПЕРТЕНЗИИ

\section{Гнатюк М. С., Коноваленко С. А., Татарчук Л. В., Ясиновский О. Б.}

Удаление правого или левого лёгкого может приводить к пострезекционной лёгочной артериальной гипертензии, венозному застою в органах большого круга кровообращения и структурно-функциональным изменениям в них. Морфологические изменения в эндотелиоцитах артерий и вен семенников при пострезекционной легочной артериальной гипертензии изучены недостаточно. Целью нашего исследования было проведения количественной морфологической оценки структурных изменений в эндотелиоцитах артерий и вен семенников в условиях пострезекционной легочной артериальной гипертензии. Морфологически исследованы семенники 46 белых крыс-самцов, которые были разделены на 3 группы. 1-я группа насчитывала 14 интактных животных, 2-я - 22 крысы с пострезекционной легочной артериальной гипертензией и компенсированным легочным сердцем, 3-я - 10 животных с пострезекционной легочной артериальной гипертензией и декомпенсированным легочным сердцем. Пострезекционную легочную артериальную гипертензию и легочное сердце моделировали путем выполнения у крыс правосторонней пульмонэктомии. Эвтаназию животных осуществляли кровопусканием в условиях тиопенталового наркоза через месяц от начала опыта. Из семенников изготавливали микропрепараты, на которых морфометрически определяли высоту эндотелиоцитов артерий и вен, диаметр их ядер, ядерно-цитоплазматические отношения в этих клетках, относительные объемы поврежденных эндотелиоцитов. Количественные показатели обрабатывали статистически. В условиях пострезекционной легочной артериальной гипертензии и декомпенсированного легочного сердиа исследуемые морфометрические параметры изменялись наиболее выраженно. Высота эндотелиоцитов артерий левого семенника оказалась уменьшенной на 2,9 \% (p<0,05), а правого - на 2,3 \%. Ядерно-цитоплазматические отношения в эндотелиоцитов указанных сосудов соответственно увеличивались на 7,6 \% и 4,7 \% (p<0,05), а относительный объем поврежденных эндотелиоцитов вырос в 11,7 и 9,3 раза ( $<$ 0,001). Исследуемые морфометрические параметры в венах семенников изменялись в большей степени по сравнению с артериями. Так высота эндотелиоцитов вен левого семенника в 
3-й группе наблюдений статистически достоверно (p<0,001) уменьшилась на 6,2 \%, а в правом - на 6,0 \%. Ядерноцитоплазматические отношения в исследуемых структурах соответственно увеличились на 8,2 \% ( $p<0,001)$ и 7,3 \% ( $p<0,01)$, что свидетельствовало о выраженном нарушении структурного клеточного гомеостаза. Относительный объем поврежденных эндотелиоцитов в венах левого семенника при пострезекционной легочной артериальной гипертензии сочетанной с декомпенсированным легочным сердцем увеличился в 17,6, в правом - в 13 раз ( $(<0,001)$. Светооптически на гистологических препаратах семенников наблюдалось полнокровие и расширение венозных сосудов, которое осложнялось гипоксией, дистрофрией, некробиозом клеток и тканей исследуемого органа, а в отдаленном периоде - инфильтративными и склеротическими процессами. Венозные сосуды микрогемоциркуляторного русла неравномерно расширены, извилистые, полнокровные, с многочисленными варикозными расширениями и саккуляциями. В указанных сосудах выявлялись стазы, тромбозы, диапедезные кровоизлияния, плазморрагии стенки венозных сосудов и паравазальных тканей. Эластичные структуры в сосудах с явлениями мультипликации, фрагментации и разрушения. Эндотелиоциты с признаками отека, дистрофрически и некробиотически изменены, местами десквамированны. В результате анализа полученных результатов установлено, что пострезекционная легочная артериальная гипертензия приводит к нарушениям клеточного структурного гомеостаза, росту относительных объемов поврежденных эндотелиоцитов в сосудистом русле семенников. Обнаруженные процессы доминируют в венозном русле левого семенника и при декомпенсированном легочном сердце.

Ключевые слова: пострезекционная легочная гипертензия, семенники, эндотелиоциты, артерии, вены, морфоометрия. 